\title{
PENGARUH PENGGUNAAN CAMPURAN ASAM AMINO ESENSIAL PADA RANSUM DASAR JAGUNG-POLLARD TERHADAP PERFORMA BABI BALI
}

\author{
WIBAWA, A. A. P., DAN I K. SUMADI \\ Fakultas Peternakan Universitas Udayana \\ e-mail: aputrawibawa@yahoo.com
}

\begin{abstract}
ABSTRAK
Penelitian ini dilakukan dengan tujuan untuk mengetahui pengaruh suplementasi campuran asam amino esensial (lisin, metionin dan triptofan) dalam ransum tradisional berbasis jagung-polar pada babi bali selama16 minggu . Rancangan yang digunakan dalam penelitian ini adalah rancangan acak lengkap dengan tiga perlakuan dan setiap perlakuan terdapat 4 kali ulangan, sehingga dalam penelitian ini menggunakan $3 \times 4$ ekor $=12$ ekor babi bali jantan lepas sapih. Perlakuan yang dicobakan kepada babi bali lepas sapih adalah perlakuan Po: ransum dasar campuran jagung dan pollard; P1: Ransum Po + campuran asam-asam amino lisin, metionin dan triptofan; dan P2: ransum standar. Variabel penelitian meliputi berat badan awal, berat badan akhir, petambahan berat badan, konsumsi ransum dan konversi ransum (FCR). Data dianalisis dengan sidik ragam bila terdapat perbedaan yang nyata maka dilanjutkan dengan uji Duncan. Hasil penelitian menunjukkan bahwa suplementasi campuran asamasam amino lisin, metionin dan triptofan dapat meningkatkan secara nyata konsumsi ransum $13 \%$, berat badan akhir $18 \%$, pertambahan berat badan $27 \%$ dan menurunkan FCR 11,61\% dibandingkan dengan ransum tradisional Dapat disimpulkan bahwa suplementasi campuran asam-asam amino lisin, metionin dan triptofan dapat meningkatkan konsumsi ransum, berat badan akhir, pertambahan berat badan dan menurunkan FCR.
\end{abstract}

Kata kunci: babi bali, ransum, asam-asam amino esensial, performa

\section{THE EFFECT OF ESSENTIAL AMINO ACIDS USE IN CORN-POLLARD BASE RATIONS ON BALI PIGS PERFORMANCE}

\begin{abstract}
This study was conducted to determine the effect of supplementation of a mixture of essential amino acids (lysine, methionine and tryptophan) in traditional corn-polar based ration in bali pigs for 16 weeks. The design used in this study was a completely randomized design (CRD) with three treatments and each treatment had 4 replications, so in this study using $3 \times 4=12$ weaning bali pigs. The treatment were Po: basic ration mixed with corn and pollard; P1: Ration Po + mixture of amino acids lysine, methionine and tryptophan; and P2: standard ration. Variables observed included initial body weight, final body weight, weight gain, ration consumption and ration conversion (FCR). Data were analyzed by analysis of variance, if there were significant differences $\mathrm{P}<0.05$ ), the analysis continued with the analysis of Duncan. The results showed that supplementation of a mixture of lysine, methionine and tryptophan amino acids could increase the ration consumption $13 \%$, final body weight $18 \%$, weight gain $27 \%$ and decrease FCR $11.61 \%$ compared with basic ration mixed with corn and pollard or traditional feed. It can be concluded that ration with mixture of amino acid increase feed consumption, body weigt, final body weight and feed efficiency.
\end{abstract}

Key words: bali pigs, ration, essential amino acids, performance

\section{PENDAHULUAN}

Babi bali merupakan ternak andalan petani di pedesaan di Bali yang dipelihara sebgai tabungan (celengan). Menurut beberapa sumber pustaka menyatakan bahwa babi bali sangat baik beradaptasi dengan lingkungan, terutama daerah panas, kurang air dan ransum yang kurang baik. Babi bali merupakan plasma nutfah yang telah dipelihara oleh petani sejak jaman dulu kala di Bali, karena bisa beranak banyak antara 8-14 ekor serta dapat dipelihara secara sangat sederhana. Pemeliharaan yang sangat sederhana 
yang dimaksud adalah; bisa diumbar, bisa diikat di bawah pohon serta diberi ransum sisa-sisa dapur. Pada beberapa tahun belakangan ini populasi babi bali menurun dibandingkan dengan populasi babi ras (landrace, large white, duroc), akan tetapi di beberapa daerah yang ketersediaan ransum babi terbatas, suhu udara yang ekstrim dan tidak memungkinkan petani memelihara babi ras, babi bali justru bisa bertahan dengan baik. Karena babi bali masih sangat dibutuhkan oleh konsumen untuk digunakan untuk upacara keagamaan dan yang paling populer adalah untuk babi guling. Kantong-kantong populasi bali seperti di Kecamatan Grokgak (Singaraja), Kecamatan Seraya (Karangasem), Kecamatan Manggis (Karangasem), Kecamatan Kubu (Karangasem), di beberapa Desa di Kabupaten Jembrana, dan Kecamatan Nusa Penida (Klungkung).

Peternakan babi bali rakyat memanfaatkan sisa-sisa dapur, daun-daunan, batang pisang, dedak padi dan bungkil kelapa sebagai bahan ransum ternak. Menurut Nitis (1967) persentase desa yang masyarakatnya memberi ransum babi dari sisa-sisa dapur $95 \%$; daundaunan $84 \%$; batang pisang $70,88 \%$; dedak padi $78,82 \%$ dan bungkil kelapa 47,64\%. Telah diketahui bahwa babi bali meruransum babi tipe pelemak, tetapi sangat digemari oleh masyarakat Bali karena sangat baik jika digunakan sebagai babi guling, karena disamping enak rasanya juga dagingnya lembut.. Sistem peternakan tradisional pada peternakan babi bali yang bercirikan (1) pemberian ransum seadanya; (2) manajemen yang jelek; (3) pencegahan penyakit yang sangat kurang dan (4) pertumbuan ternak yang sangat lambat. Menurut peneletian terakhir dari Sumadi et al. (2015), mendapatkan bahwa denga perbaikan nutrisi dalam ransum, maka pertumbuhan babi bali bisa ditingkatkan menjadi 0,35-0,5 $\mathrm{kg}$ per hari pada fase pertumbuhan. Pemanfaatan limbah pertanian sebagai ransum babi meruransum hal yang biasa, karena limbah-limbah hasil pertanian dan limbah-limbah industri hasil pertanian tersebut masih kaya akan nutrisi, seperti dedak padi, bungkil kelapa, pollard, bungkil kedelai, ampas tahu, ampok jagung dan lain sebagainya.

Penelitian mengenai pemberian limbah pembuatan sagu dari batang pohon enau yang di Bali disebut gandos telah dilakukan pada babi bali jantan lepas sapih. Padahal petani dipedesaan sudah biasa memanfaatkan gandos sebagai ransum ternak, terutama itik dan babi (Sumadi et al., 2016). Hasil Penelitian Sumadi et al. (2015) menunjukan bahwa babi-babi yang mendapat perlakuan ransum dengan $(\mathrm{ME} / \mathrm{CP}$ ratio $=3120$ kkal/19,84 \%) memiliki berat badan akhir, PBB dan konsumsi ransum paling tinggi dibandingkan babi-babi yang mendapat perlakuan $(\mathrm{ME} / \mathrm{CP}=2805 \mathrm{kkal} / 16,08$ $\%),(\mathrm{ME} / \mathrm{CP}=2950 \mathrm{kkal} / 18 \%)$ dan $(\mathrm{ME} / \mathrm{CP}=3242$ $\mathrm{kkal} / 22,28 \%)$.

Asam amino esensial yang dibutuhkan oleh babi babi sebanyak 10 asam amino. Akan tetapi yang menjadi asam amino esensial yang kandungannya terbatas pada bahan ransum nabati adalah asam amino lisin dan metionin dan triptofan (U.S. Pork Center of Excellence, 2010). Kebutuhan asam amino lisin sekitar 1,25-1,31\%, kebutuhan asam amino metionin sekitar 0,35-0,37\% serta kebutuhan asam amino triptofan sekitar 0,21$0,22 \%$ dalam ransum pada babi dengan berat badan sekitar 10-15 kg (U.S. Pork Center of Excellence, 2010; NRC, 2012). Imbangan energi-protein (energy/protein ratio) ransum babi lepas sapih menurut Ranjhan (1981) dan NRC (2012) DE (Mcal/kg)/CP (\%) : 3,2/22 atau 2,5/22; menurut CSIRO (1987) DE $(\mathrm{MJ} / \mathrm{kg}) / \mathrm{CP}(\%)$ masing-masing : 10/11.7; 12/14,8; 14/17,8 dan 16/20,9; dan menurut Ensminger (1991) ME (kcal/kg)/CP (\%) masing-masing: 3208/22.68; 3170/22,11;3050/22,34 dan 3170/22,64. Dijelaskan pula bahwa kebutuhan energi dan protein pada ternak babi sangat bergantung kepada bangsa (ras), tipe (pelemak atau pedaging), tingkat pertumbuhan (produksi) dan umur.

Ransum tradisional yang diberikan oleh peternak pada babi bali berupsa sisa dapur, campuran dedak padi atau pun pollard dan dedak jagung, serta daundaunan. Pada ransum tradisional seperti ini tidak atau jarang digunakan sumber-sumber asam amino esensial pembatas seperti tepung ikan yang kaya akan lisin dan metionin dan triptofan. Ransum tradisional yang menggunakan dedak padi atau pun pollard dan tepung jagung kalau diberikan kepada babi, sudah tentu kekurangan asam amino lisin, metionin serta triptofan.

Menurut Nitis (1967) peternakan babi bali rakyat memanfaatkan sisa-sisa dapur, daun-daunan, batang pisang, dedak padi dan usam (bungkil kelapa) sebagai bahan ransum ternak babi bali. Persentase desa yang masyarakatnya memberi ransum babi bali dari sisasisa dapur 95\%; daun-daunan $84 \%$; batang pisang 70,88\%; dedak padi 78,82\% dan bungkil kelapa 47,64\%. Dijelaskan pula oleh Nitis (1967) dan Suci (1985) peternakan tradisional di Bali yang masih memelihara babi bali tersebar di daerah Nusa Penida, Karangasem, Buleleng dan Jembana. Adaptasi terhadap mutu ransum jelek, mengantarkan babi bali mudah dapat dipelihara dan dapat beranak banyak.

Hasil penelitian Sumadi et al. (2015) menunjukan bahwa babi-babi yang mendapat perlakuan ransum dengan $(\mathrm{ME} / \mathrm{CP}$ ratio $=3120 \mathrm{kkal} / 19,84 \%)$ memiliki berat badan akhir, PBB dan konsumsi ransum paling tinggi dibandingkan babi-babi yang mendapat perlakuan $(\mathrm{ME} / \mathrm{CP}=2805 \mathrm{kkal} / 16,08 \%),(\mathrm{ME} / \mathrm{CP}=$ $2950 \mathrm{kkal} / 18 \%)$ dan (ME/CP = $3242 \mathrm{kkal} / 22,28 \%)$. 


\section{MATERI DAN METODE}

\section{Materi}

Penelitian akan menggunakan babi bali jantan lepas sapih sebanyak 12 ekor dengan berat badan rata-rata $11,52 \mathrm{~kg}$. Babi bali jantan lepas sapih tersebut di beli dari pengepul babi bali yang ada di Dusun Pegending, Desa Dalung (Badung).

Bahan-bahan penyusun ransum babi percobaan terdiri atas: jagung kuning, dedak gandum atau pollard, lisin, metionin, triptofan, konsentrat 152, garam dapur dan mineral. Komposisi bahan dan Nutrien ransum masingmasing disajikan pada Tabel 1 dan Tabel 2. Sedangkan formulasi ransum babi percobaan sebagai berikut:

Po :50\% jagung kuning, 49\% pollard, $0,5 \% \mathrm{NaCl}$ dan $0,5 \%$ campuran mineral.

P1 :Po + campuran asam-asam amino lisin, metionin dan triptofan.

P2 :ransum standar dengan $\mathrm{ME} / \mathrm{CP}$ ratio $=2800$ $\mathrm{kkal} / \mathrm{kg} / 16 \%$ (Sumadi et al. 2015).

Tabel 1. Komposisi Bahan Ransum Percobaan

\begin{tabular}{lccc}
\hline \multicolumn{1}{c}{ Nama Bahan } & \multicolumn{3}{c}{ Perlakuan } \\
\cline { 2 - 4 } \multicolumn{1}{c}{ Ransum } & P0 & P1 & P2 \\
\hline Jagung kuning (kg) & 50 & 50 & 40 \\
Pollard (kg) & 49 & 49 & 43 \\
Konsentrat (kg) & - & - & 16 \\
Mineral (kg) & 0,5 & 0,5 & 0,5 \\
Garam dapur (kg) & 0,5 & 0,5 & 0,5 \\
Jumlah & 100 & 100 & 100 \\
\hline
\end{tabular}

Tabel 2. Komposisi Nutrisi Ransum Percobaan

\begin{tabular}{lccc}
\hline \multirow{2}{*}{ Nutrien } & \multicolumn{3}{c}{ Perlakuan } \\
\cline { 2 - 4 } & P0 & P1 & P2 \\
\hline ME (kkal/kg) & 2825 & 2825 & 2794 \\
Protein Kasar (\%) & 11,84 & 11,84 & 16,15 \\
Suplemen asam amino & & & \\
$\quad$ Lisin (\%) & - & 0,75 & - \\
$\quad$ Metionin (\%) & - & 0,20 & - \\
$\quad$ Triptofan (\%) & - & 0,07 & - \\
\hline
\end{tabular}

\section{Metode}

Rancangan yang digunakan dalam penelitian ini adalah rancangan acak lengkap (RAL) dengan tiga perlakuan dan setiap perlakuan terdapat 4 kali ulangan, sehingga dalam penelitian ini menggunakan $3 \times 4$ ekor = 12 ekor babi bali jantan lepas sapih.

Perlakuan yang dicobakan kepada babi bali lepas sapih adalah perlakuan ransum yang terdiri atas:

Po :50\% jagung kuning, $49 \%$ pollard, $0,5 \% \mathrm{NaCl}$ dan $0,5 \%$ campuran mineral.

P1 : Po + campuran asam-asam amino 0,75\% lisin, $0,20 \%$ metionin dan 0,07\% triptofan.

$\mathrm{P} 2$ : ransum standar dengan $\mathrm{ME} / \mathrm{CP}$ ratio $=2800$ $\mathrm{kkal} / \mathrm{kg} / 16 \%$ (Sumadi et al., 2015).
Penelitian dilakukan di Dusun Batuparas, Desa Padangsambian Kaja, Kecamatan Denpasar Barat, Denpasar (Bali). Lama penelitian 2 minggu untuk penyesuaian ransum percobaan dan 12 minggu pengambilan data.

Parameter pengamatan meliputi performa babi bali hasil percobaan setiap 2 minggu selama 12 minggu. Performa babi bali tersebut terdiri atas: berat badan awal, berat badan akhir, petambahan berat badan, konsumsi ransum dan konversi ransum (FCR).

Data-data hasil pengamatan kemudian dianalisis dengan analisis sidik ragam (analysis of variance), bila terdapat perbedaan yang nyata $\mathrm{P}<0,05$ ), maka analisis dilanjutkan dengan analisis Duncan's New Multiples Range Test (Steel dan Torrie, 1989).

\section{HASIL DAN PEMBAHASAN}

Hasil penelitian menunjukkan bahwa berat badan awal rata-rata babi-babi penelitian tidak menunjukkan perbedaan yang nyata $(\mathrm{P}>0,05)$ diantara perlakuan (Tabel 3.). Hal ini berarti penggunaan rancangan acak lengkap (RAL) sebagai rancangan percobaan dan cara pengacakan sudah sesuai dengan metoda statistika.

Tabel 3. Performa Babi Bali yang Diberikan ransum Campuan Asam Amino

\begin{tabular}{lccc}
\hline \multirow{2}{*}{ Variabel } & \multicolumn{3}{c}{ Perlakuan ${ }^{1)}$} \\
\cline { 2 - 4 } & P0 & P1 & P2 \\
\hline Berat badan awal & $11,45 \mathrm{a}^{2}$ & $11.45 \mathrm{a}$ & $11,65 \mathrm{a}$ \\
Berat badan akhir & $27,69 \mathrm{a}$ & $32,70 \mathrm{~b}$ & $41,81 \mathrm{c}$ \\
Pertambahan berat badan & $16,24 \mathrm{a}$ & $20,65 \mathrm{~b}$ & $29,96 \mathrm{c}$ \\
Konsumsi ransum & $75,16 \mathrm{a}$ & $84,87 \mathrm{~b}$ & $107,86 \mathrm{c}$ \\
FCR & $4,65 \mathrm{a}$ & $4,11 \mathrm{~b}$ & $3,60 \mathrm{c}$ \\
\hline
\end{tabular}

Keterangan:

Perlakuan percobaan: $\mathrm{P0}$ : ransum berbasis jagung kuning-pollard; $\mathrm{P} 1$ : ransum $\mathrm{P0}$ dengan suplementasi asam-asam amino esensial 0,75\% lisin, 0,5\% metionin dan 0,07\% triptofan; P2: ransum standar dengan ME $/ C P$ ratio $=2800 \mathrm{kkal} / \mathrm{kg} / 16 \%$ (Sumadi et al., 2015). Huruf sama pada baris yang sama adalah berbeda tidak nyata $(P>0,05)$.

Berat badan akhir dan pertambahan berat badan babi pada perlakuan $\mathrm{P} 1$ dan $\mathrm{P} 2$ berbeda nyata $(\mathrm{P}<0,05)$ lebih tinggi dibandingkan dengan berat badan babi pada perlakuan Po. Keadaan ini menunjukkan bahwa babibabi yang mendapatkan ransum dengan suplementasi asam-asam amino esensial lisin, metionin dan triptofan (P1) kualitas ransumnya lebih baik dibandingkan ransum tanpa suplementasi asam-asam amino esensial (Po). Dibandingkan dengan berat badan akhir dan pertambahan berat badan standar (P2) ternyata lebih tinggi $\mathrm{P}<0,05$ ) dibandingkan dengan berat badan akhir dan pertambahan berat badan babi pada perlakuanperlakuan Po dan P1. Perbaikan mutu ransum Po dengan suplementasi asam-asam amino esensial memberikan berat badan akhir dan pertambahan berat badan yang lebih baik, lisin, metionin dan triptofan pada P1 sesuai 
dengan standar NRC (1998). Lain halnya dengan babibabi pada perlakuan P2 dengan dengan berat badan akhir dan pertambahan berat badan paling tinggi karena semua kebutuhan nutrien pada ransum P2 sudah terpenuhi sesuai dengan kebutuhan babi bali lepas sapih sampai pada fase pertumbuhan terutama ME/CP ratio sebesar $2800 \mathrm{kkal} / 16 \%$ (Sumadi et al., 2015).

Peningkatan berat badan yang lebih tinggi sebagai akibat dari perbaikan mutu ransum babi-babi yang mendapat perlakuan P1 dan P2 menyebabkan konsumsi ransum lebih tinggi $(\mathrm{P}<0,05)$ dibandingkan dengan babi-babi yang mendapat perlakuan Po, namun dari segi konversi ransum (FCR) justru pada perlakuan P2 paling kecil $(\mathrm{P}<0,05)$ (Tabel 3). Babi yang mendapat perlakuan ransum P2 merupakan babi dengan berat badan akhir dan pertambahan berat badan paling tinggi. Hal ini disebabkan babi cukup mendapat asupan energi dan dan protein serta asam-asam amino esensial (Sumadi et al., 2015).

Asam amino esensial yang dibutuhkan oleh babi babi sebanyak 10 asam amino. Akan tetapi yang menjadi asam amino esensial yang kandungannya terbatas pada bahan ransum nabati adalah asam amino lisin dan metionin dan triptofan (U.S. Pork Center of Excellence, 2010). Kebutuhan asam amino lisin sekitar 1,25-1,31\%, kebutuhan asam amino metionin sekitar 0,35-0,37\% serta kebutuhan asam amino triptofan sekitar 0,21$0,22 \%$ dalam ransum pada babi dengan berat badan sekitar 10-15 kg (U.S. Pork Center of Excellence, 2010; NRC, 2012). Imbangan energi-protein (energy/protein ratio) ransum babi lepas sapih menurut Ranjhan (1981) dan NRC (2012) DE (Mcal/kg)/CP (\%) : 3,2/22 atau 2,5/22; menurut CSIRO (1987) DE (MJ/kg)/CP (\%) masing-masing : 10/11.7; 12/14,8; 14/17,8 dan 16/20,9; dan menurut Ensminger (1991) ME (kcal/kg)/CP (\%) masing-masing: 3208/22.68; 3170/22,11; 3050/22,34 dan 3170/22,64. Dijelaskan pula bahwa kebutuhan energi dan protein pada ternak babi sangat bergantung kepada bangsa (ras), tipe (pelemak atau pedaging), tingkat pertumbuhan (produksi) dan umur.

Kualitas asam amino lebih menentukan dibandingkan kuantitas protein yang dikandung di dalam ransum. Ransum dengan keseimbangan asam-asam amino esensial akan dapat memberikan pertumbuhan atau kenaikan berat badan yang lebih tinggi. Peningkatan mutu ransum rendah sampai batas tertentu dapat menurunkan angka FCR yang artinya kebutuhan ransum untuk menaikkan satu kilogram ransum semakin sedikit. Semakin baik mutu ransum,maka pertumbuhan babi semakin baik, dehingga dengan demikian babi akan mengonsumsi ransum lebih sedikit dibandingkan dengan ransum yang berbutu lebih jelek.

\section{SIMPULAN}

Hasil penelitian dapat disimpulkan bahwa suplementasi campuran asam-asam amino lisin, metionin dan triptofan dapat meningkatkan konsumsi ransum, berat badan akhir, pertambahan berat badan dan menurunkan FCR.

\section{DAFTAR PUSTAKA}

CSIRO Australian. 1987. Rationing Standard for Australian Livestock: Pigs. Standing Committee on Agriculture: Pig Subcommittee. Esat Melbourne, Australia.

Ensminger, M.E. 1991. Animal Science. $9^{\text {th }}$ Ed. International Publisher Inc., Illinois.

U.S. Pork Centre for Exellent. 2010. National Swine Nutrition Guide. U.S. Pork Center of Excellence. 1776 NW 114th St. Des Moines, IA 50325.

Nitis, I.M. 1967. Makanan Babi di Bali (A Preliminary Survey). Univiversitas Udayana. FKHP Bull. 013.

NRC. 2012. Nutrient Requirements of Swine. $10^{\text {th }}$ Ed. Rev. United State Dept. of Agriculture, USA.

Ranjhan, S.K. 1981. Animal Nutrition in Tropics. $2^{\text {nd }}$ Ed. Vikas Publishing House PVT Ltd. Delhi, India.

Suci, N.N. 1985. Pengaruh Suplementasi Silase Limbah Ikan Mackerel dan Rumput Laut Dalam Ransum Tradisional Terhadap Performa Babi Bali yang Sedang Tumbuh. Tesis S-2 Fakultas Pascasarjana, Univ. Gajah Mada, Yogyakarta.

Sumadi, I.K., I.M. Suasta dan I.P. Ariastawa. 2015. Prosiding SENASTEK II 2015 : Inovasi Humaniora, Sains dan Teknologi untuk Pembangunan Berkelanjutan. Tanggal 29-30 Oktober 2015, Patra Jasa Bali Risort and Villas, Kuta, Badung (Bali). 